\title{
Jamestown's Relics: Sacred Presence in the English New World
}

\author{
Christopher M.B. Allison
}

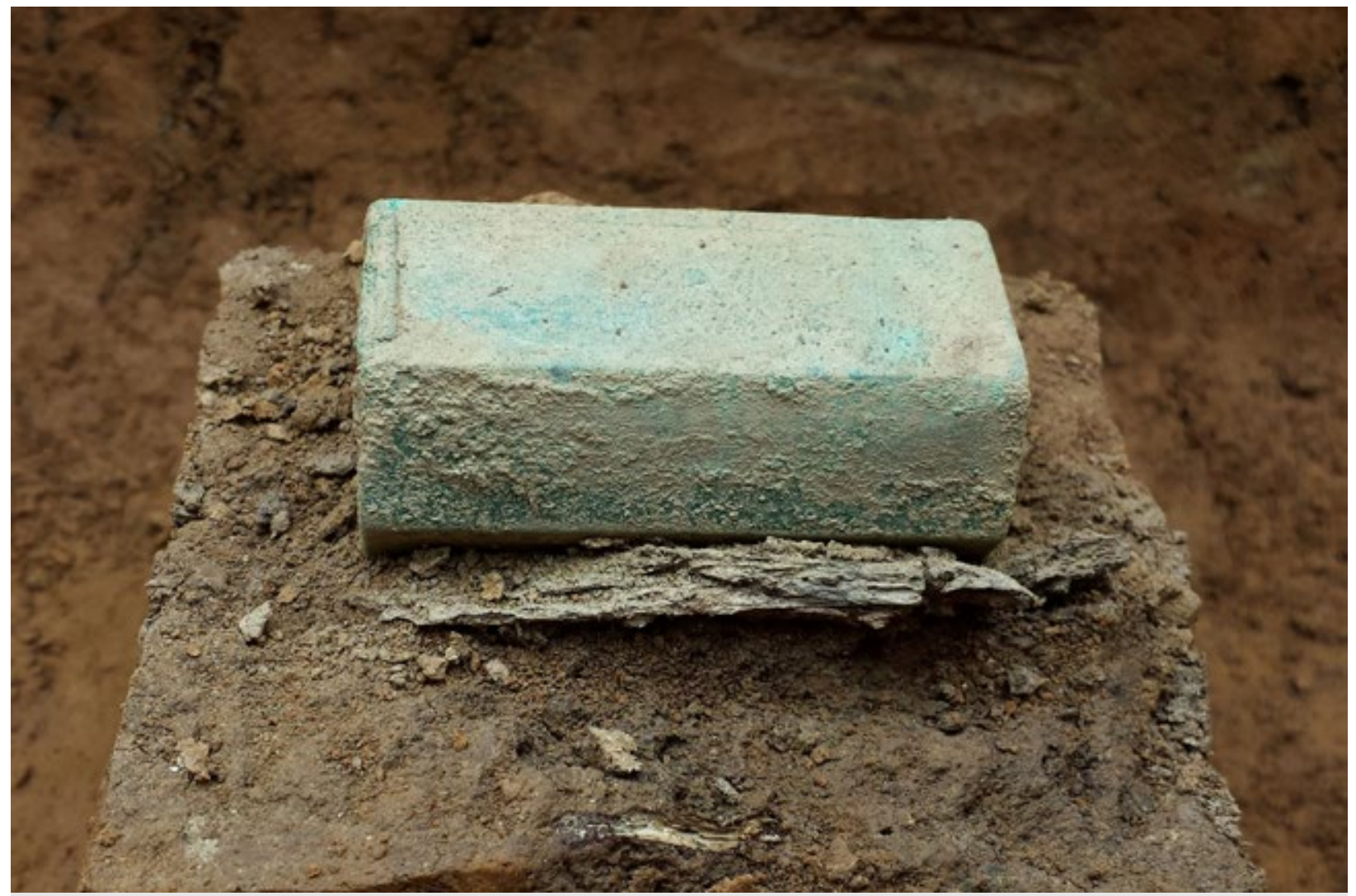

Fig. 1 Reliquary in situ, sitting above the coffin detritus in the grave identified as that of Captain Gabriel Archer. Image courtesy of Jamestown Rediscovery (Historic Jamestowne).

In the harsh winter of 1609-1610, settlers at Jamestown placed a small silver case with a slide opening etched with a single letter $-\mathrm{M}-$ carefully on top of a white oak coffin and then covered it with the hard, cold dirt of the New World. Inside the silver encasing were seven bone fragments and two lead ampulae filled with water, oil, dirt, or blood-relics of an unknown saint or saints that came to rest in Virginia. The settlers placed these on top of a coffin, a box filled with the corpse of a deceased English colonist.

When the news broke in 2015 that archaeologists had uncovered a reliquary in Jamestown, some authors intimated that it would force us to reconsider the history of early America anew. ${ }^{1}$ Others suggested that the public and those involved in archaeological findings should know better, that the religious diversity among early settlers had long been established in the scholarship. ${ }^{2}$ Both perspectives have some validity, but the discovery demonstrates that our greatest insights and questions can come from the ground. The reliquary's preeminent value-and why it deserves to be considered as remarkableis as a material source that raises new questions and helps us imagine new possibilities around the earliest English settlement in North America. The diversity of religious life 
in Virginia has been known textually, but not viscerally. There lingers a broad Protestant patina across the scholarship of English settlement in Americas, in large part because of its textual backing. The reliquary, however, reveals practices that rarely show up in written records, it gives a heightened dimension to the political dissension, economic turmoil, and religious infighting in early Jamestown and forces us to acknowledge a deeper history for the early United States, one rooted in historical periods and places that few Americanists consider, such as Medieval Europe and the Late Antique Mediterranean. The object has a particular power to materialize different histories that textual sources cannot, undermining with startling efficiency the clear boundaries between the Catholic and Protestant "new" worlds. Robert Orsi has recently challenged scholars of religion to contend with the presences of the "gods" in history. These presences take up historical space, he argues; they are living, immanent presences in the lives of religious people and thusly are very much in history, not above or absent from it. ${ }^{3}$ In the Jamestown relics this point is materialized in a place that is still too often seen as a blank slate ready for powerful Protestant colonist interventions by a collectivity of people who hedged against the errors of the old world in the new. The reliquary and its contents declare the material presence of the saints in the English New World-in its history-through bones and dried liquid covered in lead, encased in a hexagonal silver tube. This media of saintly presence prompts many questions that open up new lines of inquiry on the Jamestown settlement, the settlers, and the origins of English empire: what was the role of the material culture of religion in the colony? What does the Jamestown reliquary, its relics, and its burial tell us about the colony? What continuities from previous eras of relic culture are present? And what alternative histories did the reliquary suggest (Fig. 2) This essay will begin with the object itself, and then examine it within the broader context of early Jamestown, early modern English society, and the history of relics, reliquaries, and church architecture from late antiquity to the seventeenth century.

Holding the reliquary in the palm of one's hand is instructive. It is small, measuring just under three inches in length and an inch and a half in diameter. Conservators at Jamestowne Rediscovery have meticulously restored it, freeing its silver encasement of the green oxidation from sitting in the invariably wet clay soil of James Fort for over four hundred years. It has heft. As it is moved back and forth you can hear and feel that there are loose things inside, imbuing it with a sense of mysterious liveliness. Its slide top has corroded shut. The contents, however, are clear, thanks to CT scans which revealed the bone fragments to be tibia and allowed the conservators, archaeologists, and anthropologists at Jamestowne Rediscovery and the Smithsonian Museum of Natural History to know the exact dimensions of the contents. ${ }^{4}$ They have created a reproduction, which helps further our understanding of the sealed object (Fig. 3). In essence, the reliquary is a combination object; it holds seven human bones and other effluvia, presumably human, related to an unknown saint or saints enclosed in the two lead containers; all encased in an opaque silver tube with a slide opening.

Historians at Historic Jamestowne have identified the body that lay in the coffin on which the reliquary was placed as that of Captain Gabriel Archer, a victim of the infa- 


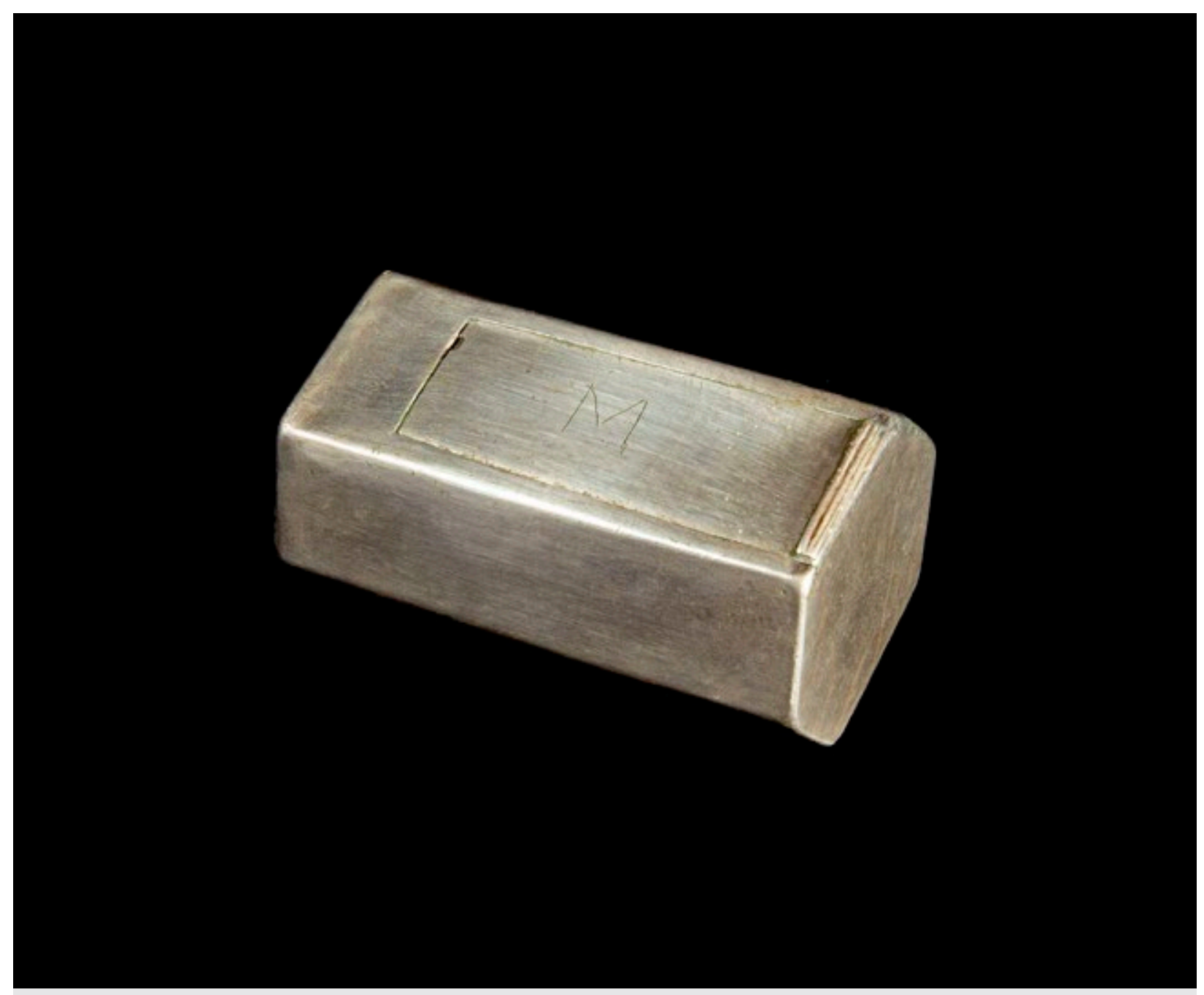

Fig. 2 Reliquary after preservation. The fine silver work of the hexagonal tube is juxtaposed with the crudely made M, scratched on the slide opening. Image Jamestown Rediscovery (Historic Jamestowne). 


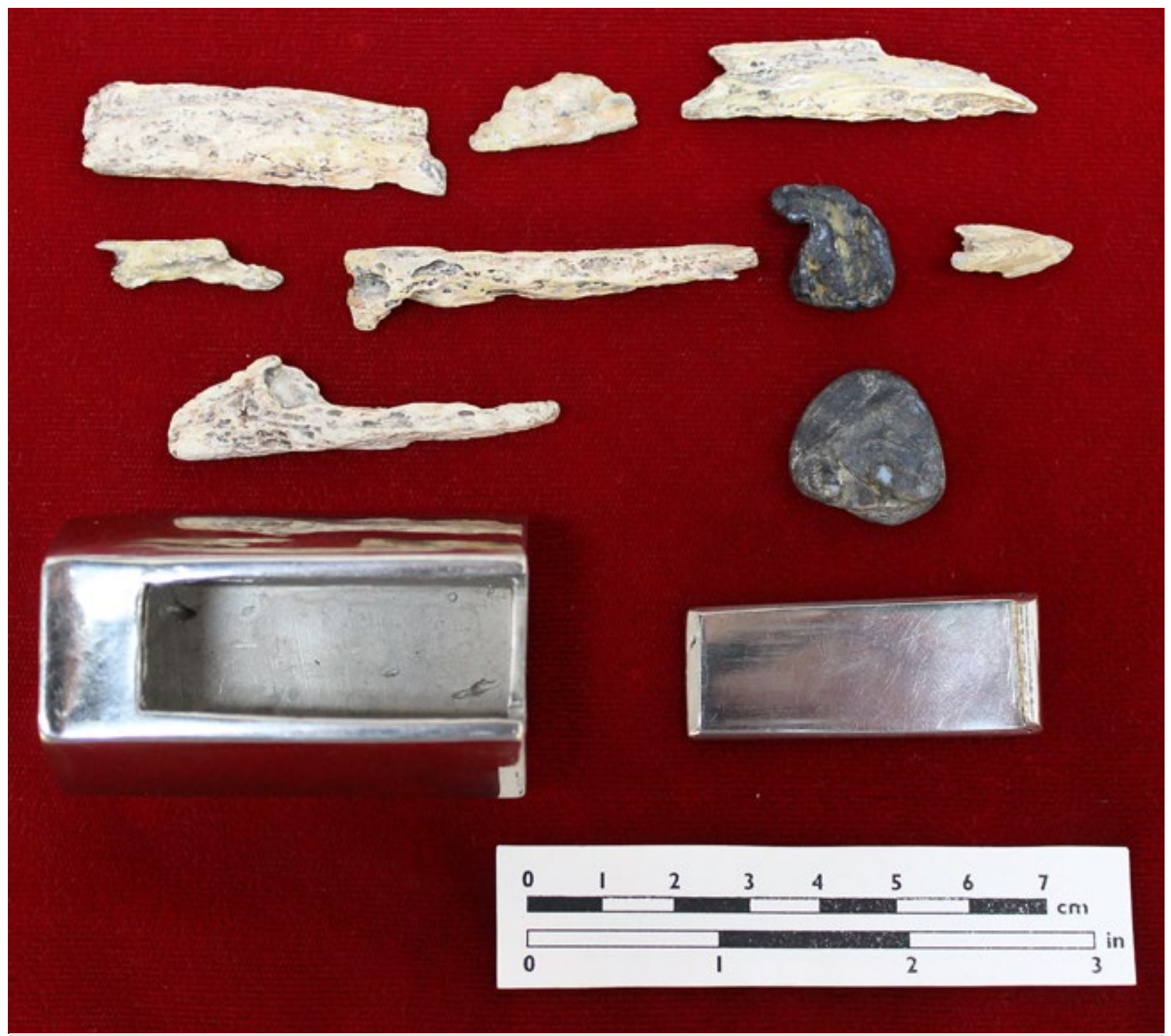

Fig. 3 View of the reproduction of the reliquary and its contents. Photo by author, permission of Jamestown Rediscovery (Historic Jamestowne).

mous "starving time"-a winter of want that led some colonists to cannibalism. ${ }^{5}$ Despite the acute stress in the fledgling settlement, Archer was given a distinguished burial. Archer was educated at Cambridge and served as the colony's first lawyer; he wrote several narratives of the settlement and attained the honorary rank of Captain. Not only did fellow settlers produce a fine coffin for Archer, but they buried him with his Captain's staff, a spear adorned with a finial, a symbolic object of his earthly rank. Unlike the vast majority of the growing numbers of colonists who died during that harsh winter, he was buried indoors, inside the newly constructed "chapel." It was a building of rather large proportions for such a small, fragile settlement. Being a chapel, it was not cruciform like most English churches, but a long rectangle; John Smith described it as "a homely thing like a barne [sic]." ${ }^{6}$ Cedar planking covered the chancel area, with a black walnut altar on top, and before it a rail for individuals to receive the Eucharist; it was below this area that settlers laid to rest four bodies of leading men of the community, including that of Archer (Fig. 4). ${ }^{7}$ They were laid, however, in different directions. ${ }^{8}$ Did this mean 


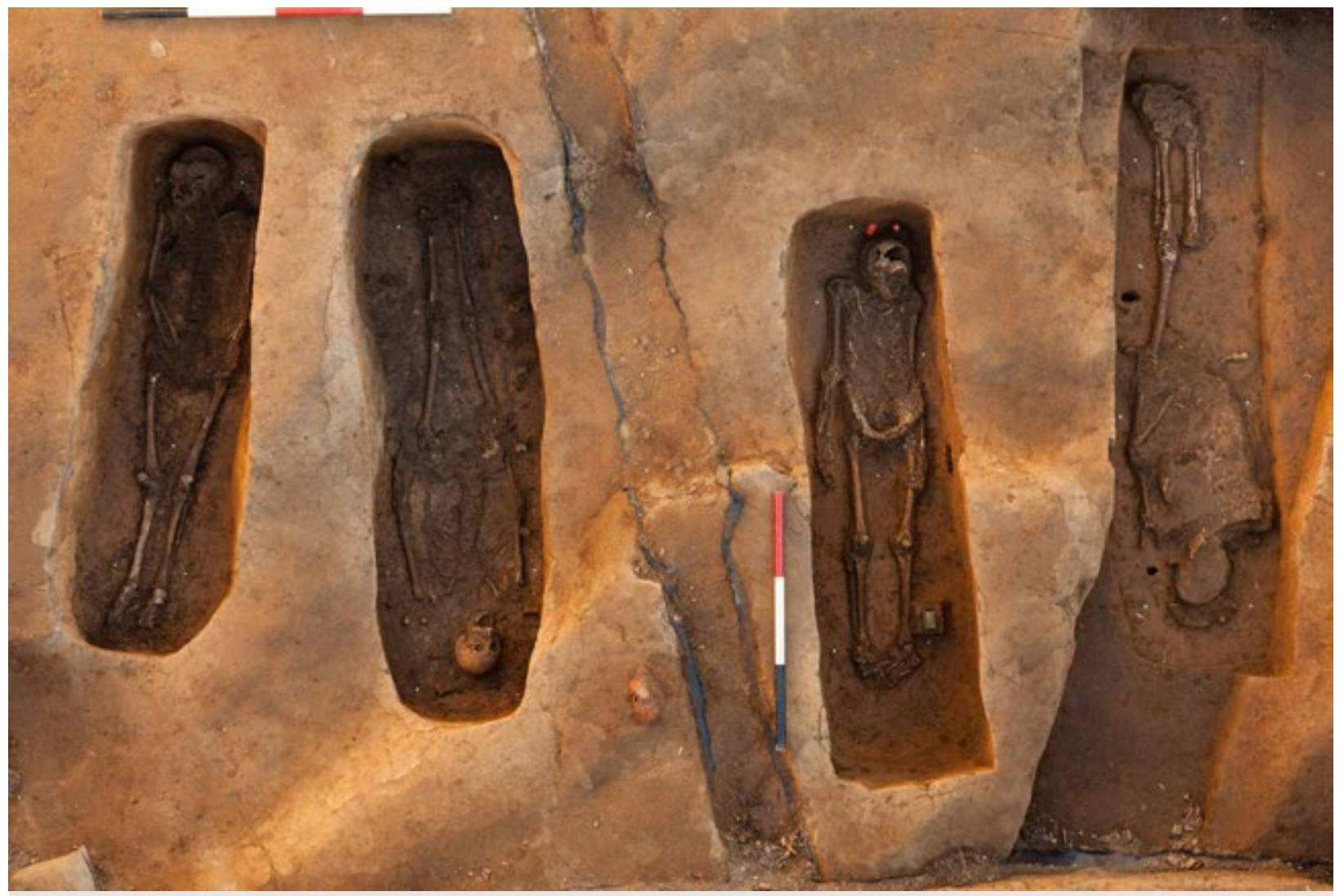

Fig. 4 The four chancel burial excavations at Jamestown. Buried from left to right, Reverend Robert Hunt, Sir Ferdinando Wainman, Captain Gabriel Archer, and Captain William West. All of the bodies are buried on the traditional east-west axis. Hunt and Archer's heads are in the east, and Wainman and West's are in the west. In Archer's grave, you can see the reliquary's placement at his feet, aligned with the direction of his body, and perpendicular to the probably placement of the altar. Photo courtesy of Jamestown Rediscovery (Historic Jamestowne).

something? Although traditional English burial practice in this period prescribed that all deceased be buried on an east-west axis, some sources note a distinction between the laity and the clergy. Laypeople with their heads in the west, so that upon the resurrection of the dead their faces would be turned east towards Jerusalem, in full view of Christ's return to earth, and clergy facing west, to look in victory upon the faces of their freshly resurrected flock, a consummation of their earthly ministry. ${ }^{9}$ All the bodies in the chancel are buried on the same east-west line, but Archer faces the same direction as the recently deceased minister, Reverend Robert Hunt. Was this intentional?

It is hard to say. On the one hand mortuary practice is a highly stable aspect of human cultural practice and in most circumstances very intentional. It is important to remember that all the bodies were buried at different times; it seems unlikely that the Jamestown settlers possessed a perfect knowledge of the placement of the individual's bodies. So it is uncertain if those who buried Archer knew about Hunt's burial direction and intentionally made a connection between the two men's vocations. Once a body is buried, it is hard to check the circumstances of the burial without great effort. While all four were dutifully buried along the traditional east-west axis, it is impossible to know if the placement of their heads in different directions was intentional. If it was intentional, it 


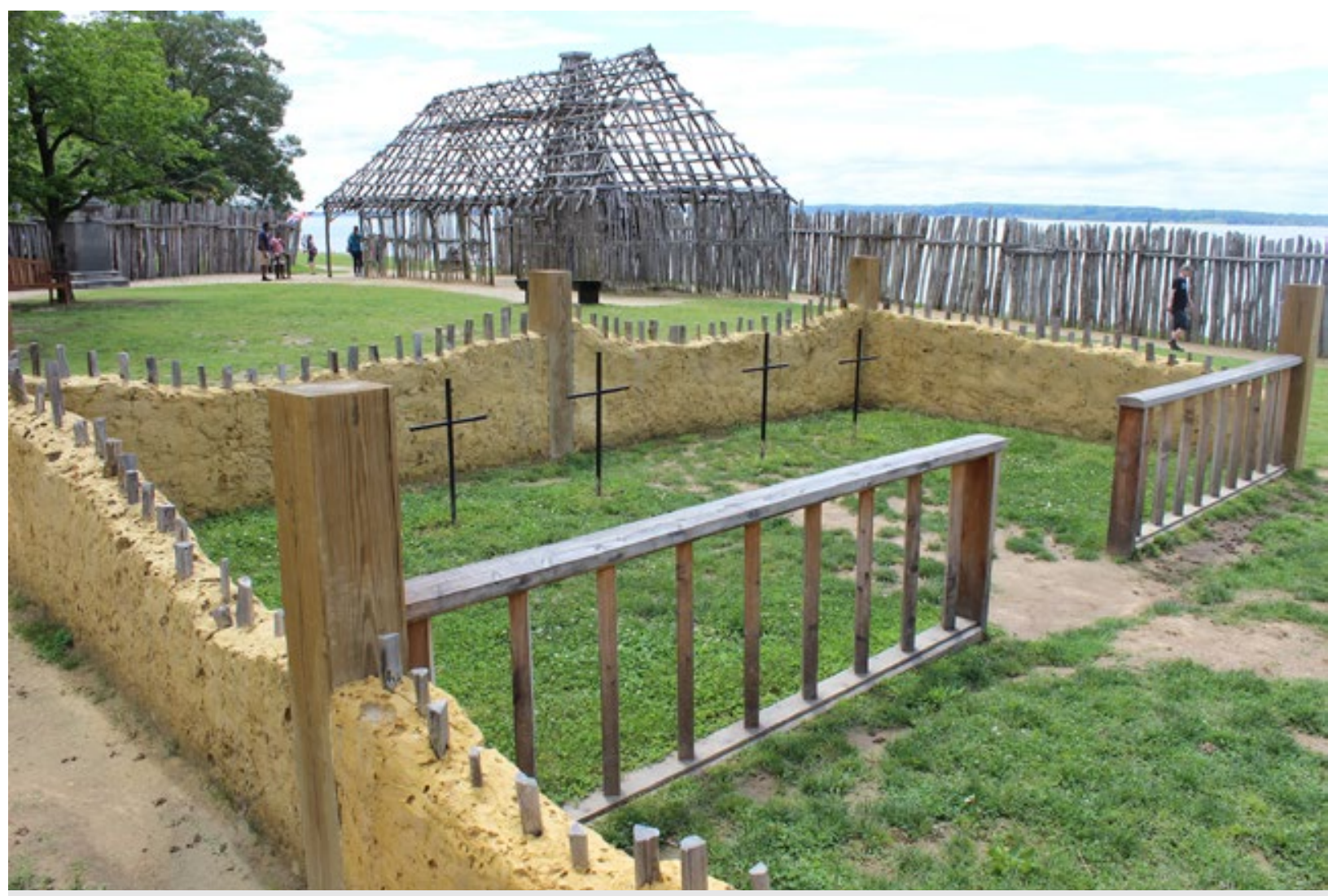

Fig. 5 View into the chancel of the partial reconstruction of the chapel on the original site at Jamestown. Archer was buried below the third cross from the left. The placement of the crosses, walls and communion rail are modern, based on archaeological evidence. Photo by author.

might suggest that Archer had taken up some kind of ministerial role. There is no corroborating evidence, however, of Archer's formal training as a priest or of lay ministry. The burial of ministers with their head in the east was not a consistent or universal practice-it was more of a selective cultural lean. Moreover, we have no evidence that Archer traveled to the Continent for training as a Catholic priest, which would have been the typical path in the period. In his written work he does not evince a particularly ministerial bend.

What is more illuminating is that all four of the burials were in the chancel, the area near the altar, usually separated by some kind of division from the nave, the long space for the congregation (Fig. 5). The burial of prominent members below the floor of a church was a common English practice from the medieval period-especially for parish dignitaries-known as burial ad sanctum-near the altar, near the saints, near the sacred. Chancel burials in particular were reserved for the clergy and local landed families. The latter pushed for chancel burials in the sixteenth and seventeenth centuries in England in response to the ending of monastic burial in 1535 through the Suppression of Religious Houses Act passed by Parliament at the urging of Henry VIII. Landed families had usually received monastic burial in exchange for offering some kind of sponsorship of the monastery or convent. Dignitaries wanted their bodies installed in places surrounded by monks or nuns-vocational interceders-who would pray for the souls of 
those around them, and do so around the clock. As Thomas Laqueur has shown, even if prayers on behalf of the dead were no longer theologically sensible in the new order, given the Protestant attack on intercession for the dead, the interest in being buried within sight of priests and parishioners and their attendant prayers persisted. ${ }^{10}$ Chancels in particular became places of lay sponsorship after the Reformation. With this sponsorship, elite families, even Catholic ones, not only claimed the right to burial within the chancel, but also incorporated the rights and responsibilities of the chancel ministry into their estates. As Laqueur pithily notes, "Place trumped faith." ${ }^{11}$ Although the possibility of Archer as a minister is intriguing, and there would have been acute demand for pastoral care, no less for the sacraments, there are more obvious reasons why he would be buried in this location. In Jamestown Archer would have had a claim on the chancel as a prominent member of the colony, as a landowner, and probably as a sponsor of the parish, perhaps even of the chancel ministry.

The reliquary's placement on top of Archer's coffin, aligned with it along the east-west axis, placed the relics in close proximity to the altar above, a revealing choice in light of the historical association of altars and relics. The placement of relics in and below altars has a deep history from the origins of the cult of the saints in late antiquity. In the early Christian period, churches began to be built around or on top of the tombs of martyrs and saints; later, relics began to be "translated" from their original burial places into worship spaces. For example, Ambrose of Milan in $386 \mathrm{CE}$ disinterred the corpses of two local saints from the cemetery outside the city walls and installed them below the altar of his newly constructed basilica. In doing so, Ambrose redirected the veneration of the saints' remains from the outskirts of the cities to the altar, the focal point of liturgical space in the church, where the Eucharist was celebrated. Placing martyrs below the altar had scriptural warrant as well. Revelation 6:9 notes that upon opening the "fifth seal" John the Revelator "saw under the altar the souls of them that were slain for the word of God, and for the testimony which they held.” Ambrose, along with African church leaders, initiated a collective move that would soon disperse martyrs and other holy people from their resting places at the edges of Roman cities to the architectural centers of Christian devotion. ${ }^{12}$ This occurred despite being, at the time, a violation of imperial Roman law..$^{13}$ This precedent held tremendous sway over the centuries to come. The Second Council of Nicaea in 787 prescribed that all churches have relics installed near or in the altar. Charlemagne set the requirement into law. The Council of Trent reiterated the practice in the face of the Reformation assault on the cult of the saints. Many altars were designed to bring the saints even closer to the celebration of the Eucharist-by boring holes into the altar itself where relics could be placed. There within the altar the presence of the saints, their virtus, as it was known, abutted the ritual celebration of Christ's sacrifice, in which the real presence of Christ was realized. (It was a hard requirement to keep up, however, and in the twentieth century Roman Catholic churches were given some latitude on the requirement to have saints' remains, in colonial Latin American churches the presence of an icon near the altar was often deemed sufficient.) ${ }^{14}$ Furthermore, there was an understanding that relics, if placed not in the altar but buried below, should align perpendicularly with the altar, even as the placement of the reliquary on the coffin, near Archer's feet, perpendicularly aligns it with the probable placement of the altar. ${ }^{15}$ Jamestown's altar would have been rudimentary at best, even ephemeral, so 
placing sacred remains in the altar would have been foolhardy. Burial was more secure.

James I's succession from Elizabeth I seemed to predict a stable Protestant trajectory for England and its feeble but growing empire, but the situation remained contentious. This continuing turmoil and instability would impact both the visibility and location of relics in English society. The religious instability of the pre-Elizabethan era was a constant traumatic memory. English priests trained at the special English colleges on the European continent (Douai, Rheims, Rome, Valladolid, Seville) infiltrated England beginning in 1574 on a mission to turn the English soul back to Rome. Jesuits arrived in 1580 . Of the 471 seminary priests who were active during the reign of Elizabeth I, almost two thirds of them were imprisoned, one hundred and sixteen were executed, seventeen died while in prison, and ninety-one were banished. Elizabeth effectively rooted out, banished, and executed many of them, in part through her successful intelligence efforts. ${ }^{16}$ Still, this influx of English priests who sought to rally sympathetic English Catholics was a reminder that the Protestant Queen had not vanquished challengers from within, even if she decisively defeated the Spanish Armada in 1588 from without. The wind surely seemed to blow in a Protestant direction, but instability threatened again and again. The famous gunpowder plot of 1605, alternatively known as the "Jesuit Treason," attempted not only to kill James I, but also to spur a country revolt in the Midlands around the claims of the Catholic Princess Elizabeth. Although those involved in the plot to destroy the King and members of both houses of Parliament in one fell fireball explosion possessed diverse motives, scholarly consensus is clear that, in the words of Mark Nicholls, "every Gunpowder plotter hankered, to some degree, after a restoration of Catholicism..." 17 The instability persisted into the later part of the seventeenth century (long after Archer's death at Jamestown), with the English Civil War, the Puritan reign of Oliver Cromwell, and the ascent of the openly Catholic James II to the throne from 1685-1688. While the infamous iconoclasm of the English reformation extended to the relics of the saints, it was not as destructive as one might think. Reformers tore down many shrines-and plundered their valuables-but parishioners often buried the remains of the saints quietly below where the shrine once stood. ${ }^{18}$ At the same time, the stripping of Catholic liturgical space had the immediate countervailing effect of massive domestication of relics in English Catholic households. English Catholics placed relics, no longer safe in shrines, monasteries, or churches, into hiding in their homes. As these Catholics kept the island's sacred bodies in their cupboards, waiting for a future retranslation back into liturgical space, so too the reliquary sat below the altar in Jamestown, waiting for the eventuality that the English crown should swing back to Rome. ${ }^{19}$ It was not uncommon for relics, if remembered, to be exhumed or at least for the presence under the altar to become openly acknowledged. Relics placed along the axis of the altar satisfied an old requirement in a very new place, open to an unpredictable future.

Perhaps the placement of the reliquary on Archer's coffin was more personal, an attempt to join a saintly life with a singular life. This impulse has a history. Although being buried with objects was rare in seventeenth-century English mortuary practice-a simple burial shroud was the norm-many of the leaders of Jamestown were buried in their clothing with their ceremonial staffs on top of their coffins. ${ }^{20}$ Clothing, like other objects, was valuable, and rarely consigned to the grave. The Jamestown settlers, however, were far more concerned with food than clothes. Nonetheless, grave objects are unique 
among the other burials at Jamestown. Being buried with relics is a layered, folded practice. It joins a material body with an exceptional body. From the beginnings of the cult of the saints, elite patrons tried to join their burial with that of their heavenly patron-a martyr or saint-hoping their proximity would aid them in their aspirations for eternity. In $295 \mathrm{CE}$, for example, the wealthy gentlewoman Pompeiana obtained the corpse of the martyr Maximilianus from the magistrate in Thavaste (modern Algeria) over the claims of his kin and transported the body to her hometown of Carthage. ${ }^{21}$ There she buried the corpse at the bottom of a hill next to the body of St. Cyprian, another martyr. After concentrating these two saintly bodies, she died two weeks later and was buried next to them. The grieving father of Maximilianus was apparently overjoyed at the result. His martyred son, through the earthly patronage of a noblewoman, gained proximity to another saintly life, a heavenly patron. The interest in being buried near the saints was enduring and became a major impetus for interment within the confines of churches and near shrines. Proximity was power. People with temporal power were particularly competent in orchestrating proximity to the heavenly. Archer had temporal power; perhaps he sought the heavenly analog in death and as such wished to be buried with the reliquary.

Archer could not be buried without help and the way in which he was buried attests to the great respect with which he was regarded in Jamestown. Attacking enemies through the poor treatment of their remains was a common anti-Catholic tactic in England, but the condition of Archer's body speaks to none of this. This raises the question as to who laid Archer into the ground. There is a long history of those who care for the dead assisting the deceased in accessing the spiritual power they sought in life, usually try to reconstruct the intentions of the deceased or, ideally, carry out their explicit wishes. Although sometimes, for superseding reasons, they act on their own, there is little evidence of rogue activity around Archer's interment. His burial is distinguished, not hasty, nor disrespectful. The defiling of a corpse was a common punishment for unrepentant English Catholics, but there is no evidence of any such desecration. In fact, given the circumstances of "the starving times," the burial was lavish. ${ }^{22}$ Archer was the leader of a faction within the colony and the loss of a leader in a difficult political climate is as much about honoring the dead as it is about the future. Those who buried Archer ignored their hunger pangs, built a coffin, laboriously dug the heavy cold clay from the base of the chapel, and set their leader to rest, in a coffin, with his captain's staff and his reliquary carefully set on top. Those who buried Archer lifted up his example by lowering his body respectfully to the ground.

Burying Archer with the reliquary could have been intended to simply mark him as a Catholic, making visible his religious identity. Indeed, Archer's political alliances followed rough Catholic lines; during Archer's lifetime Jamestown's colonists brought up two Catholics for charges of espionage. These men were Archer allies, but extant sources offer no signs of true Catholic sympathy on Archer's part. Perhaps the placement of the reliquary on his coffin honored his Catholic upbringing, or maybe it was intended to remove an assemblage of troublesome sacred objects from circulation. Here Archer's family history is germane. Archer was raised in a family of "recusants," Catholic faithful who refused to attend services at the local English parish church. His parents had paid fines for their absence, were known to authorities in Essex, and even had other recusants 
living under their roof. ${ }^{23}$ Around the time of Archer's birth, Essex had a small recusant population clustered around the home of the wealthy Catherine Audley, but the group faced intense pressure from local authorities loyal to Queen Elizabeth, in large part due to their proximity to the ports. Local recusants could host Catholic priests, nuns, and students traveling back and forth from the Continent. There is evidence that the concern on the part of local authorities was warranted, for many priests and nuns were caught in Essex in the homes or inns of local Catholics. ${ }^{24}$ Nonetheless an ostensibly Catholic upbringing did not entail a lack of loyalty to the Crown. Gabriel Archer was a bombastic presence in early Jamestown, especially in his opposition to Captain John Smith, but he wasn't outspoken in terms of religion. In fact, Archer was one of the most energetic promoters of the Virginia Company from the start; there are no signs of equivocation in his commitment to English advance in North America, nor to the reign of James I. At the end of his "Brief Description of the People," one of the most elegant narratives of the Jamestown settlement, Archer gives a view into the practices of the local Indians, ending his narrative thus:

To conclude, they are a very witty [cunning] and ingenious people, apt both to understand and speak our language, so that I hope in God, as $\mathrm{He}$ hath miraculously preserved us hither from all dangers, both of sea and land and fury, so He will make us authors of His holy will in converting them to our true Christian faith by His own inspiring grace and knowledge of his deity. ${ }^{25}$

Here Archer gives a broad Christian gloss to the hopes of converting the local Indians; he encapsulates the religiosity of the English in a capacious phrasing that suggests unity and belies the presence of religious tensions: "our true Christian faith." ${ }^{26}$ At least for his readers in England, Archer narrated commonality in religious mission, not difference. His readers would have interpreted this characterization not as a progressive ecumenical gesture, expressing the equivalency of a wide range of Christian traditions, but rather as a commonality centered on the professed Protestantism of the Church of England. Archer, like all colonists to Virginia, swore (it seems in good faith) allegiance to the King, including a denial of Papal authority. Openly Catholic settlers were not required to make the same oath.

Religion emerges in passing here and there in the three extant Archer narratives, almost always in a political context or in relation to the Indian population. One narrative, attributed to Archer by scholars, relates an intriguing political moment during an expedition up the Powhatan River, now called the James River, where the English settlers met with "Great King Powhata," the ruler of the Powhatan federation of Indians west of Jamestown. "King" Powhatan was in as much need of allies as the besieged English, thus he sought to extend his political power among the region's various Indian groups. The English settlers' venture up the river was a mixture of diplomatic mission, ethnographic exploration, and territorial scouting. Archer related the story of Captain Christopher Newport's arrival near the "mouth of the falls" of the river, by modern Richmond, where the group erected "a cross with this inscription: 'Jacobus Rex.1607"' in the nearby presence of a small group of Powhatan's followers. ${ }^{27}$ Archer noted that upon the "erecting thereof we prayed for our king and the prosperous success in this his action, and 
proclaimed him king with a loud shout." ${ }^{28}$ Captain Newport interpreted the cross to the Indian observers in a different way. He told them, in a moment of disingenuous translation, that the "two arms of the cross signified King Powatah and himself, the fastening of it in the midset was their united league, and the shout the reverence he did to Powtah, which cheered [the Indians]." ${ }^{29}$ Archer related the prayers, cross, and shouts for James I, including his own, in a positive light, and took note with some distaste of Newport's dishonest translation of the object and the meaning of their activity. In sum, Archer appears in full support of his king's claims on the New World in association with the religious object, just as he was in support of the spread of Christian religion among the Amerindian population.

Material symbols are culturally and politically flexible. In the early settlement, the acute concern, in terms of religion, was geopolitical, both in reference to distant Europe and to more immediate relationships with the local Indian population. James I had recently brokered a tenuous peace with Spain's Phillip (Filipe) I. In the Virginia interior, Newport sought to reassure Powhatan of English support for his rule through a makeshift cross, devoted originally not to their relationship, but to the English king. The Virginia Company endeavored simultaneously to make money, to spread the Christian message, and to establish a foothold in a New World dominated by the Spanish. ${ }^{30}$ The issue of Catholic and Protestant contention came up in the colony only when it was a question of espionage. In 1608, the colony brought the two Catholic settlers previously mentioned up for charges of conspiracy. The first was Captain George Kendall, who was first imprisoned, then convicted of being a spy for the Spanish and shot to death for mutiny. ${ }^{31}$ The other was Edward Maria Wingfield, then president of the governing council, whose political rivals suspected him of conspiracy for his open Catholicism. He was ultimately acquitted and sent back to England. In fact, Wingfield's initial dismissal from the governing council stemmed not from his Catholicism, but from complaints that he had been tight-fisted with food supplies and, moreover, that he was not religious enough. Wingfield reported in his defense that he had been accused of atheism since he "carried not a Bible." 32 The material culture of religion, or in Wingfield's case, the lack thereof, mattered in the public space of the colony. The colonial leaders sought to inculcate piety-compelling everyone to attend church services-but also religious harmony in hopes of scaring off sedition. John Smith, for example, believed that this was a strength of the Ottoman empire, being united "generally of one religion," while "the Christians in so many divisions and opinions... are among themselves worse enemies than the turks." ${ }^{3}$ "Therefore," Smith argued, "I doubt not but you will seeke [sic] to the prime authority of the Church of England." 34 In 1619, about ten years after Archer's death, John Pory, a secretary to the Governor of the colony, visited Jamestown. In a letter to the treasurer of the Virginia Company, Pory criticized the conduct of "Mr. Chanterton," whom he stated, "smells too much of Rome." 35 The evident cause of the so-called smell for Pory was Chanterton's attempts to "worke myracles $w^{\text {th }}$ his Crucyfixe," an index for Pory of Chanterton's stubbornness in "mayntaining his sensles religion." ${ }^{6}$ Pory's suspicion that Chanterton had come "hither as a spy," was reinforced by Chanterton telling Pory that he had been in "Rome in Octobr Last." ${ }^{37}$ For Pory, this was a conspicuous religiosity that did not inculcate harmony. In the end, however, the local administration ruled that they would "take no notice." ${ }^{8}$ Early leaders surely found the Catholicism of these men sus- 
picious, but not necessarily damning; the trials and accusations to which they subjected potential Catholics turned on their loyalty to the colony and Crown, not whether they owned crucifixes or relics, or sought the intercession of the saints. This was consonant with James I's policy regarding religion; he was willing to allow some religious toleration insofar as he could expect political loyalty.

It is important here to disaggregate the geopolitical issues between Catholic and Protestant powers from those of religious practice. The Church of England was preeminently Protestant in its rejection of the authority of the Pope and embrace of vernacular English in both worship and the Bible. In terms of religious practice, however, the Church of England was far more of a hybrid, never engaging in the comprehensive reforms of worship, theology, or church space that the more radical Protestant sects achieved on the Continent. Even the 1549 Book of Common Prayer retained Latin titles to help jog the memory of those immersed in the rituals of the pre-Reformation church. The Protestant Queen herself, Elizabeth I, maintained a crucifix above her private altar. Reform waxed and waned, reversed and advanced, but was never complete. So if the Church of England represented a hybridized Protestantism, the archaeological evidence reveals that early English settlers of Virginia likewise embraced a hybrid faith. Archer could profess loyalty to his Protestant king, while also remaining committed to the practices of an older order. He was not alone. Archaeologists working at Jamestown have found a wide range of religious artifacts at the site, including ecumenical book clasps, presumably to hold together unwieldy Bibles or other devotional books-but also more explicitly Catholic jet crucifixes, rosary beads, silver and copper medallions, and other devotional objects such as cross coin necklaces (Fig. 6). ${ }^{39}$ The material composition of these objects, much like that of the reliquary, indicates a Continental provenance, which aligns with the production of devotional objects in the period, especially from Spain where silver was abundant from its colonial mines (especially Potosí in modern Bolivia), and the workshops of the Catholic Low Countries. Acquiring such objects would not have been hard. As historian Karen Kupperman has demonstrated, many of the early settlers of Virginia-especially its leaders-lived remarkably transnational lives, spanning the Protestant, Catholic, and Ottoman worlds. Captain John Smith, for example, bumbled through France, was thrown overboard in the Mediterranean for being a "Hugonoit" by a "rabble of [Catholic] Pilgrimes...going to Rome," fought a Venetian ship between Egypt and Italy, helped end the siege of an Ottoman city in Hungary, decapitated three Ottoman officers in one-onone combat in Romania, was enslaved in a territory near the Black Sea, escaped, traveled to Germany, France, and Spain, and then to northern Africa again. ${ }^{40}$ After returning to England, to cap it all off, he signed up to go to Virginia.

The Jamestown reliquary and the relics it contains are a remarkable discovery, but they can also be contextualized within both the broad material culture of the cult of the saints and the immediate context of post-Elizabethan England. Simple silver hexagonal and octagonal tube reliquaries were not the most common form of reliquary; even "mass-produced" reliquaries tended to be more ornate..$^{41}$ A significant class of "casket reliquaries" existed on the market, mirroring in miniature the commonplace repository of human remains, but these reliquaries usually possessed flat bottoms. Hexagonal and octagonal long reliquaries did have a particular cachet in the devotional lives of elite families, especially in the Byzantine world, but most of these tube reliquaries-called 


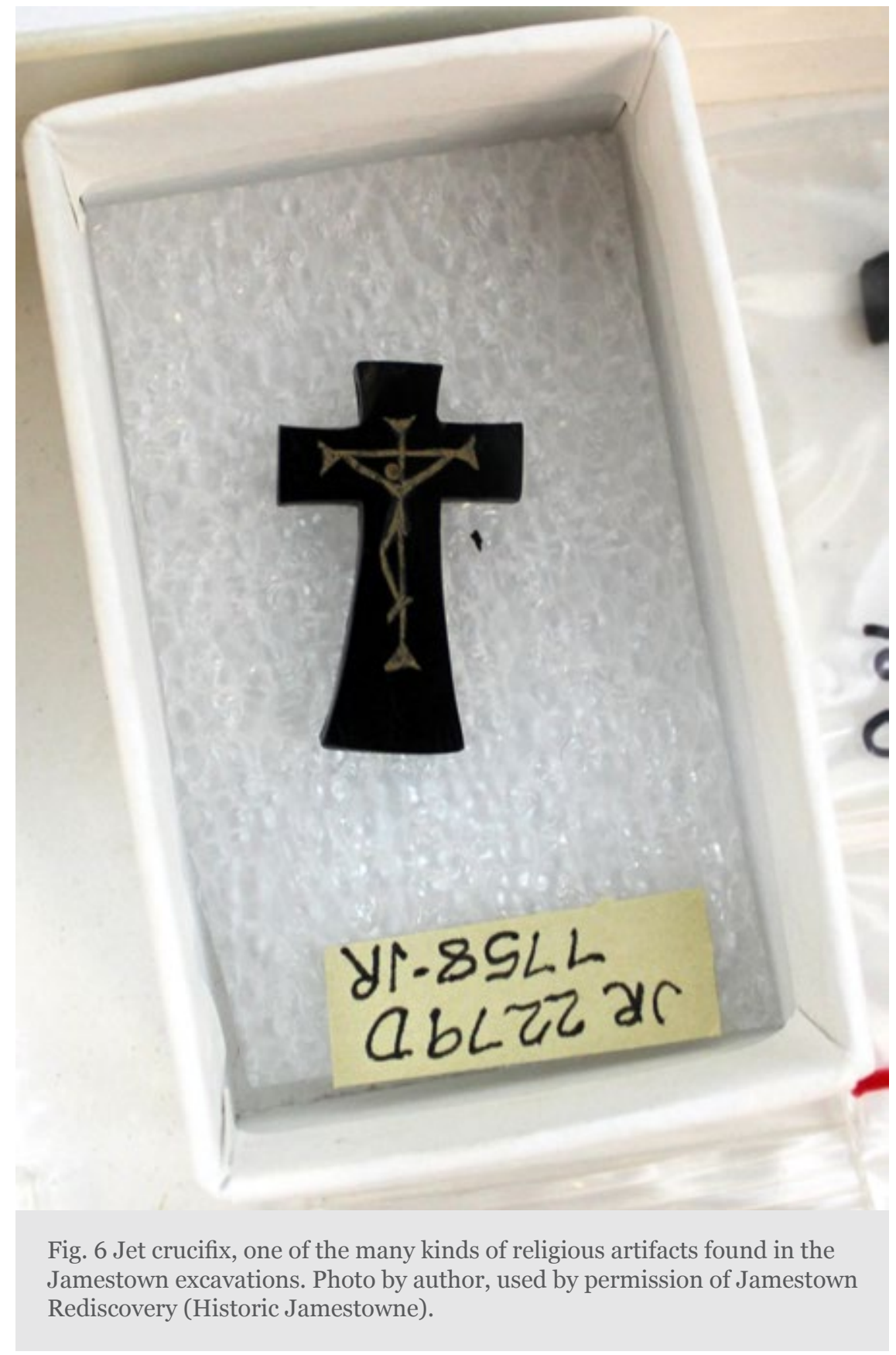

capsae-had design elements-loops-that allowed them to be worn on the person, most likely around the neck. ${ }^{42}$ The Jamestown reliquary possesses none of these design elements; it is much shorter and wider-more akin to the silver stems that supported crucifixes, suggesting the possibility that it might have been refashioned from one of the many destroyed crucifixes of the sixteenth century. ${ }^{43}$ Furthermore, unlike the Jamestown reliquary, capsae did not usually contain "primary" relics, meaning the actual bones or bodily remnants of a given saint. Rather, these personal reliquaries most often housed secondary relics, such as cloth or oil that had passed across the sainted body. The Jamestown reliquary both holds primary relics and may also house some secondary relics in the ampullae. The slide opening of the Jamestown reliquary, just like that of 
capsae, suggests a design made for frequent access. It lacks a clasp or device to keep the slide top in place, presenting the real danger of its accidentally opening, divulging its precious contents. Therefore it seems unlikely that the Jamestown reliquary was carried around in everyday affairs. Rather it lived, as it were, in a more stable place. ${ }^{44}$

Reliquaries worked on behalf of their sacred contents, naming the holy body held within, narrating its life, but also directing the senses toward the divine. As Cynthia Hahn has observed, in the medieval context the apprehension of the reliquary not only taught devotees the nature of divine aesthetics, but was understood to reform them from the inside out through the sensational encounter with divine beauty. The reliquaries and relics-as a duo-worked alongside the narrative of the given saint's life-oral, written, or illustrated. All these elements collaborated to create a vision of true divine beauty often set in a sacred architectural space. To apprehend a holy life was to see and feel these things at once, never fixating on a single element. Hugh of Saint-Victor, the medieval Saxon mystic and theologian, for example, saw this process of devotees encountering holy people as like wax impressed by a seal; through intensive prayer and contemplation the Christian devout could achieve a pliable humility that allowed them to be shaped by the stamp of the likeness of God made manifest in holy lives. ${ }^{45}$ Reliquaries crucially framed-or more literally contained-the holy lives necessary for this work. Reliquaries separated the human detritus inside from the ubiquity of human and animal bodily matter outside, erecting a precious wall in between. Separation, or setting apart, is a key factor in maintaining the sacred. The reliquary did this work in a material way, as well as assuring the devotee that the contents were indeed sacred. Provenance, or the history of possession, did matter after the Renaissance (Erasmus, Calvin and the Council of Trent all agreed); devotees needed assurances that the matter they venerated was real. ${ }^{46}$ Maintaining provenance and setting apart holy matter, however, did not preclude the devotional demands of touch and access. The value of relics was the work they did in the temporal world and this work required proximity. As sacred as relics and their mediating reliquaries would be, their value as devotional objects was thoroughly immanent. Although many people in the modern world encounter reliquaries most commonly behind museum glass, relics and the reliquaries that encompassed them were for the daily lives of living people. The material culture of the cult of the saints was, in Peter Brown's words, an effort of "joining Heaven and Earth." 47

Reliquaries participated in this work, while also making it clear who should be looked to in order to receive the impression of a divine example, their designs often suggesting the sacred identity of the individual(s) contained within. While silver was indeed precious and associated with the sacred, the Jamestown reliquary is comparatively mute among reliquaries of the early modern period and before. Most reliquaries are highly expressive, combining text, image, and precious material, revealing the labor of countless unnamed artisans, patrons, and clergy in elevating exceptional Christian lives. Artisans embellished reliquaries intended for communal liturgical use with elaborate gilding, jewels, or colored enamel, often giving them rock crystal viewing windows, marking them with the name of the saint or with scenes from the saint's life. The reliquary was frequently etched, stamped, or illustrated with this crucial information; sometimes the shape of the reliquary mirrored in design the body part within-all to denote that the bodily fragments inside were veritable "treasures of heaven." 48 The use of silver on the 


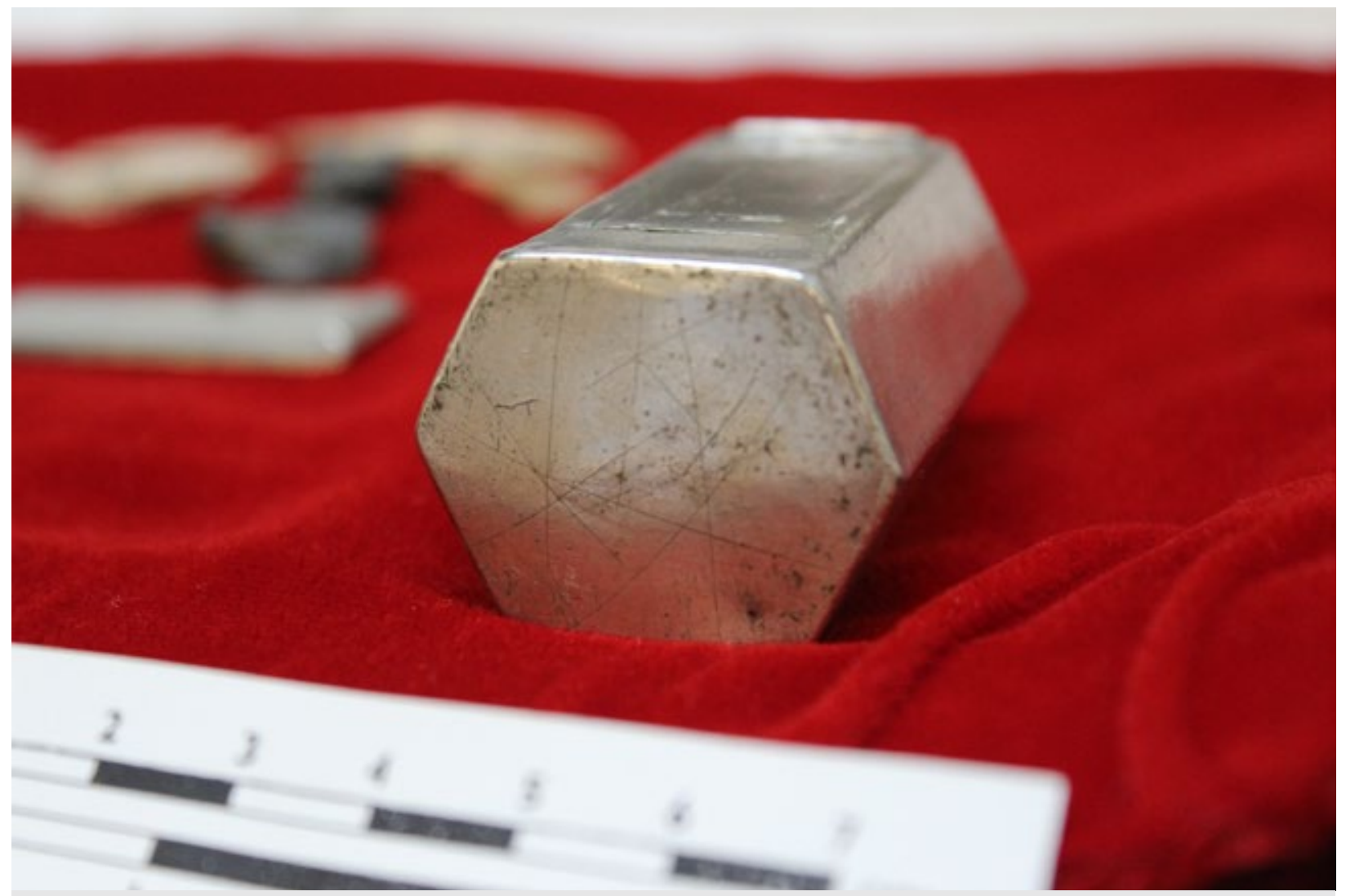

Fig. 7 Scratches detail on the end of the reliquary forming three stars. Photo by author, used by permission of Jamestown Rediscovery (Historic Jamestowne).

Jamestown reliquary suggests a treasure within, but its comparative lack of adornment implies a private use in which elaboration and narration of the relics was unnecessary. The owner knew who was inside and whose presence the remains invoked. Simplicity reflected its private use; silver marked the object's contents as precious.

Markings on reliquaries served a crucial role in identifying their otherwise indistinguishable contents. On one end of the Jamestown reliquary, a series of scratches form five pointed stars (Fig. 7). On the other end, there are markings that form a rudimentary arrow symbol. In both cases it is hard to immediately see their significance or register intentionality. Perhaps the arrow symbol references the origin of the Archer name, derived from the family's service as archers to the King of France. What was clearly intentional is the letter "M," prominently etched on the surface of the sliding lid. Given the history of reliquaries of all stripes, this "M" most likely refers to the saint whose remains are contained within. Since human remains are notoriously difficult to keep straight (one of the Protestant Reformers' main criticisms of the cult of the saints ${ }^{49}$ ), it was important to seal the reliquary to prevent tampering, theft, or switching the sacred remains for profane. It was also essential that it be labeled. Sealing and labeling maintained provenance-assurance that the contents were real-especially for primary relics. Alexander Nagel has argued that this is the reliquary's essential role-to maintain the connection between a holy life and holy body. The reliquary fuses the life and the remains together. ${ }^{50}$ The letter $\mathrm{M}$ seems to have served this purpose on the Jamestown rel- 
iquary. Given the crude marking, it seems unlikely that the silversmith carved the letter, more likely a subsequent handler felt the need to add this identifying mark. The labeling is clear but also vague, the $\mathrm{M}$ could refer to any number of saints. This lack of precise labeling might suggest a need for secrecy, but more likely functioned as shorthand for private knowledge of the saint's identity. The easily moved slide lid-much like that of capsae-seems to suggest that the danger of tampering was low and the desire for access high. So whose sacred remains are contained within?

Despite the intent of reformers and iconoclasts to destroy relics, no less mock and expose as them as frauds, the vast number of relics in English monasteries, cathedrals, and churches in 1530 s and 1540 s escaped destruction and made their way into the homes of the Catholic faithful. For example, in 1559, John Jewel, the English Bishop of Salisbury, related the story of a former caretaker of the erstwhile Benedictine Abbey at Glastonbury salvaging a nail from the ruins of the monastery. The caretaker understood the nail to have been used in Christ's crucifixion, brought to England by Joseph of Arimathea. Even when Jewel removed the nail from the old man's home, the elderly caretaker remained devoted to the impression it had left on the linen in the reliquary, which gained a reputation for working miracles. ${ }^{51}$ The presence and the absence of a relic held power. Some relics reemerged during the reign of Queen Mary, but most stayed in the cupboards, as it were. When English missionaries returned to England in 1574 they discovered an unregulated domestic cult, which alarmed them, for it often appeared more magical than reverential. The Council of Trent had reaffirmed the Church's commitment to the cult of the saints, but also instituted strict new regulations in response to reformers within and without Catholicism. In England the informality of Catholic practice made these new rules difficult to enforce, leading to what historian Alexandra Walsham describes as, "a large mobile library of miraculous objects that persistently defied the efforts of the clergy to supervise their use." ${ }^{2}$ Archer's family could easily have hosted displaced relics from the former holy places of England, but a more interesting possibility points to the relics of contemporary Catholic martyrs killed during the reign of Elizabeth I. Recusants immediately treated these martyrs as saints; as Cardinal William Allen observed, those who sought the bodies of these martyrs had a "godly greedy appetite of holy persons." 53 Furthermore, the public desecration of the martyrs' bodies by Protestant magistrates made them readily available to devotees. As Walsham writes, "Catholics scrambled to collect fragments of their flesh, dip cloths and handkerchiefs in their blood, and to gather up their cassocks, garments, and stockings, spectacles, rosary beads, crucifixes, letters, and other possessions, along with the equipment used to put them to death." ${ }^{54}$ They even raided the prison cells of priests in anticipation of their martyrdom; the cells themselves became places of miracles. These new martyrs of the so-called Protestant Queen created a thriving and enthusiastic trade in relics among English recusants. ${ }^{55}$ The list of Christian saints that begin with the letter " $\mathrm{M}$ " before the seventeenth century is voluminous, but if we look at the list within the context of Elizabethan recusant Catholics and their passion for contemporary martyrs, the list gets much smaller. ${ }^{56}$ In fact, it narrows around a particular martyr.

The strongest candidate for the " $M$ " is Cuthbert Mayne (Fig. 8). In fact, Mayne's execution in November of 1577 was the beginning of the new fervor for modern English Catholic martyr relics. ${ }^{57} \mathrm{He}$ was the first of the seminary priests trained on the Continent 


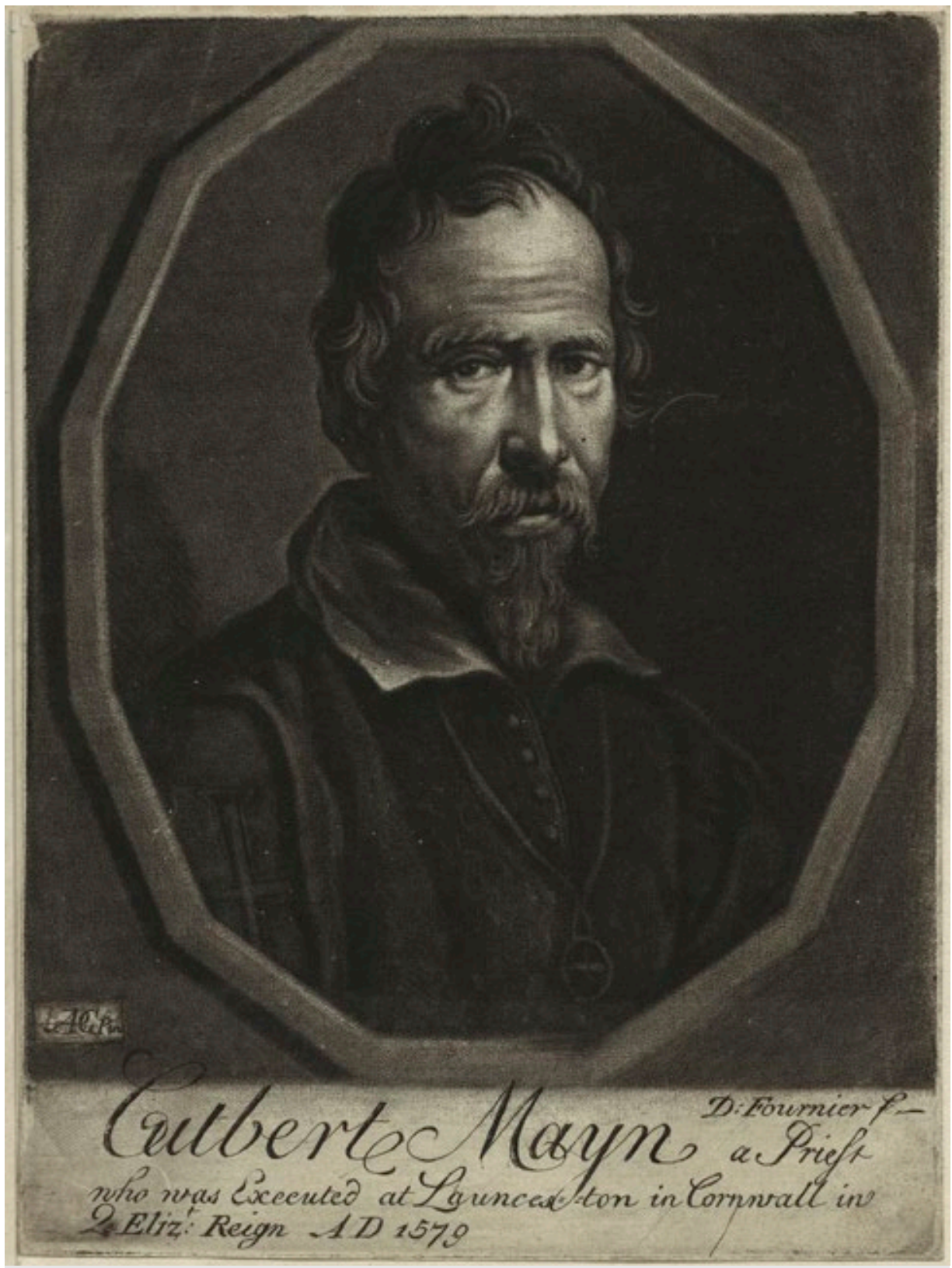

Fig. 8 Daniel Fournier, Cuthbert Mayne, mezzotint, probably early to mid 18th century, 6 1/4 in. x 4 3/4 in., Gift of Mary Elizabeth Stopford (née Fleming), 1931. National Portrait Gallery [UK], London. Image courtesy of the National Portrait Gallery.

to rally English Catholics back to the Roman faith, the first to be tried for treason, and the first to die. As was mentioned earlier, after Catholicism was banned in England, a series of seminaries in Catholic Europe sponsored the training of Englishmen to be sent back to serve the embattled Catholic population. In Mayne's case, the evidence was thin for a capital charge, yet the authorities pushed his conviction and subsequent execution through an ambivalent court to act "as a terror to the papists." ${ }^{8}$ His declaration both in court and at the gallows that the Queen was not the spiritual leader of the Church of England sealed his fate, but saying Mass and possessing an Agnus Dei necklace and a printed copy of a papal bull for a jubilee aggravated his cause. Mayne's execution demon- 
strated not only how dangerous the possession of Catholic material culture could be, but also revealed the particular danger of expressly denying the Monarch's authority over the English church-a lesson not lost on recusant survivors. Mayne's followers reported that the night before his execution his jail cell beamed with supernatural light. As they did with many other Catholic recusants, Mayne's executioners mutilated him terribly, dragging him through the streets before hanging and quartering him and then removing his heart from his chest to show it to the crowd. The side effect of this dismemberment was that it made his bodily remains easily accessible to those who sought his relics. The desecration of a body among one party can create the fragmentation necessary for broad material devotion of another. For example, the executioners removed his head and displayed it on a pike, but at one point a person friendly to Mayne took it down and kept it safe, likely in their home, until toleration could allow the object to surface. Modern-day devotees at Mayne's shrine at the Catholic parish church at Launceston, in Cornwall (the site of the majority of Mayne's ministry), bring out the skull on special pilgrimage days in June. Despite the strong regional differences in the period, there were significant connections between Cornwall and Essex, Archer's family home. Mayne had corresponded with Essex recusant John Neale; perhaps this epistolary connection led to the gifting of Mayne's relics to Essex Catholics. ${ }^{59}$ The enthusiasm for recusant martyr relics, along with Essex's history of harboring seminary priests and connections to Cornwall, made this transfer of relics possible.

The potential need for discretion on the part of a recusant family in possession of relics of a Catholic priest martyred by the state offers a possible explanation for the unique design of the reliquary. A silversmith could easily produce a box of this type for a range of purposes, unaware of the family's designs. Later a family member could identify the saint within with a simple, crude-but opaque-M. If one was in the know, it was obvious, but, if discovered, it was immediately unclear what the object was or what the $\mathrm{M}$ meant. This may have been exactly what the Archer family wanted-to simultaneously hide and venerate the objects within. The slide opening allowed for easy access or addition to the collection. Did Archer, fearing the worst in the bleak winter of 1609, slide open the top, handle the precious objects inside, and seek the intercession of the saints? Did he feel abandoned by them and God? Or did he accept his fate and hope his patron in heaven would help him achieve eternal life?

The Jamestown reliquary expands the frame of study of early American European settlement and the stories we tell about religion therein. In 1509 and 1510 there were no saint's shrines in North America and the English New World is probably the last place we would expect to find relics. But the saints were materially present in Jamestown, the heart of English imperial designs in the New World. Despite the diversity that many historians have recognized in textual primary sources about early American religious life, these text-based insights have not transferred beyond the scholarly guild. Objects possess physical tenacity that can broaden our thinking in ways that appeal to specialists and the broader public alike. As modern scholars of material culture have pointed out, objects are querulous agents of history; their persistence allows them to act on a timescale of unexpected duration. ${ }^{60}$ The intentions of the settlers who buried Gabriel Archer with the reliquary and the relics within are murky. Yet the reliquary at that somber, cold funeral of Gabriel Archer brought the presence of a saint (or many) to bear on the space, 
on the corpse below, and among those who buried him. Regardless of whether the relics were of Cuthbert Mayne or not, the reliquary's burial in the chancel indexed a religious practice with no shortage of political implications, acting to permanently install holy matter in the architectural center of the colony's religious life. Unearthed four hundred years later, it acts again, shifting assumptions about the nature of the arrival of Europeans on the edges of the American continent. This is why the reliquary graced the New York Times's front page and was featured in a bevy of other periodicals. It is important, almost instinctually so.

The reliquary is remarkable because of the questions that tumble forth, even if they return only partially answered. The cult of saints-the signature phenomenon of post-Constantine Christianity-lived on in Virginia, despite the colony's New World Protestant pretensions. This object materializes the relationships and histories early English colonists brought with them to the New World. We know these settlers brought disease, death, warfare, religion, enslaved Africans, and unquenchable ambition. But they also brought their difficult religious histories, including relationships with unseen presences that the Atlantic Ocean did not and could not sever. This reliquary and the relics sealed within materialize these presences and make them historically visible. Archer's reliquary stabilized a set of relationships that many reformers wished would evaporate in the wake of their iconoclasm and scorn. Relics can be hidden in cupboards and placed in silver tubes on top of coffins in chancels. The presence they invoked was surely masked but not erased, domesticated but not destroyed, buried but not absent. To paraphrase Michel Serres, the relics in English Catholic households made the revolution occurring in English religious culture slow and open to reversal. ${ }^{61}$ Despite the perennial Protestant claim of new starts, the cult of the saints persisted amid the foundations of an avowed Protestant venture into the New World. A budding Protestant empire began with the saints in its midst and under its floorboards. ${ }^{62}$

Acknowledgments: I want to especially thank Merry A. Outlaw, Curator of Collections, and the staff at Jamestown Rediscovery for their accommodating hospitality, assistance, and level of access they provided in researching this subject, including James Horne, Michael Lavin and the other conservators and archaeologists on site. I am grateful for the insights, encouragement, and critical feedback of the two anonymous reviewers. Thanks to Emily Floyd and Sally Promey at the Yale Center for the Study of Material and Visual Cultures of Religion for their enthusiasm, John Hanson, Assistant Curator of the Byzantine Collection of Dumbarton Oaks, Washington, D.C., Thomas Laqueur, at the University of California, Berkeley, Erik Seeman at the University of Buffalo, as well as staff from the Victoria and Albert Museum and the National Portrait Gallery (UK), London. Early proofs were read by the Early America Workshop at Harvard University, special thanks goes to Carla Cevasco, John Bell, Brett Culbert, Jennifer Chuong, and Alicia DeMaio.

(C) Christopher M.B. Allison

Christopher M.B. Allison is a Loeb Fellow at the Center for American Political Studies and Ph.D. Candidate in the History of American Civilization, Harvard University. 


\section{Citation Guide}

1. Christopher M. B. Allison, "Jamestown's Relics: Sacred Presence in the English New World," Essay, in Conversations: An Online Journal of the Center for the Study of Material and Visual Cultures of Religion (2016), http://mavcor.yale.edu/ conversations/essays/jamestown-s-relics-sacred-presence-english-new-world

Allison, Christopher M. B. "Jamestown's Relics: Sacred Presence in the English New World." Essay. In Conversations: An Online Journal of the Center for the Study of Material and Visual Cultures of Religion (2016). http://mavcor.yale.edu/ conversations/essays/jamestown-s-relics-sacred-presence-english-new-world

\section{Notes}

1. Nicholas Fandos, "Unearthing Jamestown's Leaders, and a Mystery," The New York Times, July 28, 2015, https://perma.cc/DY3S-47YT

2. Ed Simon, "Will This Relic Change Our Whole View of Early American History?” Religion Dispatches, August 7, 2015, https://perma.cc/D65J-7FE7

3. Robert A. Orsi, History and Presence (Cambridge, MA: The Belknap Press of Harvard University Press, 2016), 69. doi:10.4159/9780674969056 As Orsi writes, “...the routes of presence go right through the material and political circumstance of everyday life,” and because of this they "are not innocent, nor are the practices and media of presence associated with them," or above the fray. "The gods may align themselves with some against others. They may be called on to sanction or witness acts of violence, or even to do violence. And because the gods are not transcendent, but immanently present, humans are compelled to ask whether the gods have caused their pain and suffering, and if so, why."

4. See the following for a video on the reliquary, including two three dimensional models of the object before and after conservation, hosted by the Smithsonian Institution. See “Reliquary," Jamestown Rediscovery: Historic Jamestowne, accessed January 28, 2016, http://historicjamestowne.org/archaeology/chancel-burials/archaeology/ reliquary/ (or https://perma.cc/YDA5-TGFM).My thanks to Michael Lavin, archaeologist and senior conservator at Jamestown Rediscovery, for recounting his experience of uncovering the reliquary in the original excavation.

5. No work has kept such a laser focus on the "horror show" that was early Jamestown than the important Kathleen Donegan,Seasons of Misery: Catastrophe and Colonial Settlement in Early America, 1st ed., Early American Studies (Philadelphia: University of Pennsylvania Press, 2014), 69-116. doi:10.9783/9780812209143

6. John Smith, The Complete Works of Captain John Smith (1580-1631) in Three Volumes, ed. Philip L. Barbour, vol. 3 (Chapel Hill: Published for the Institute of 
Early American History and Culture, Williamsburg, VA by the University of North Carolina Press, 1986), 295.

7. William Strachey, A Voyage to Virginia in 1609: Two Narratives: Strachey's “True Reportory" and Jourdain's Discovery of the Bermudas (University of Virginia Press, 2013), 79-80.

8. The arrangement of the chancel burials can be seen at "Chancel Burials," Jamestown Rediscovery: Historic Jamestowne, accessed January 28, 2016, https://perma.cc/ H9KE-AF8N

9. W. J. Mike Groen, Nicholas Márquez-Grant, and Rob Janaway, Forensic Archaeology: A Global Perspective (Chichester, U.K.: John Wiley \& Sons, 2015), 511. doi:10.1002/9781118745977 The explanations among various sources differ on why clergy face west, or if laity are to face Jerusalem or the Rising Sun (both of which are associated with Christ's return in the New Testament). Some sources cite confidence on the part of the clergy in their salvation so that they have no need to face the approaching Christ. See Roderick Sprague, Burial Terminology: A Guide for Researchers (Lanham, MY: Rowman Altamira, Rowan \& Littlefield, 2005), 107. Others note the tradition of clergy facing west as deriving from the "Paris Rite," namely the Gallican Liturgy attributed to Saint Germanus of the Sixth Century (a source revered and ignored in varying degrees in Anglican circles). SeeNotes on Ceremonial from the Antient English Office Books: With the Order of the Holy Communion and Ritual Directions for Choral and Plain Celebrations of the Holy Eucharist, Solemn Evensong, and Funerals (London: Pickering and Chatto, 1888), 172.

10. Thomas W. Laqueur, The Work of the Dead: A Cultural History of Mortal Remains (Princeton, New Jersey: Princeton University Press, 2015), 115, 122.

11. Ibid.

12. Ann Marie Yasin, "Sight Lines of Sanctity at Late Antique Martyria," in Architecture of the Sacred: Space, Ritual, and Experience from Classical Greece to Byzantium, ed. Bonna D. Wescoat and Robert G. Ousterhout (Cambridge; New York: Cambridge University Press, 2014), 248-50. doi:10.1017/cbog781139017640.010 Arnold Angenendt, "Relics and Their Veneration," in Cynthia J. Hahn et al., Treasures of Heaven: Saints, Relics, and Devotion in Medieval Europe (New Haven: Yale University Press, 2010), 21.

13. Galit Noga-Banai, The Trophies of the Martyrs: An Art Historical Study of Early Christian Silver Reliquaries, Oxford Studies in Byzantium (Oxford: Oxford University Press, 2008), 133.

14. Beth Williamson, “Altarpieces, Liturgy, and Devotion,” Speculum 79, no. 2 (2004): 354-56.doi:10.1017/s0038713400087947 Olinda Celestino, "Offerings to the Saints in Colonial Peru: Economic Aspects of the Andean Ritual System in the Eighteenth 
Century," in Manipulating the Saints: Religious Brotherhoods and Social Integration in Postconquest Latin America, ed. Albert Meyers and Diane Elizabeth Hopkins, WAYP-8 (Wayasbah-Publication) (Hamburg: Wayasbah, 1988), 130-31. United States Conference of Catholic Bishops, "On the Arrangement and Ornamentation of Churches," in The Roman Missal, English translation according to the third typical edition (Chicago: Liturgy Training Publications, 2011), 69. The relaxing of the requirement to have holy matter installed in the altar was after the 1969 revision of the Missale Romanumafter the Second Vatican Council.

15. Noga-Banai, The Trophies of the Martyrs, 137.

16. Eamon Duffy, "Allen, William (1532-1594)," Oxford Dictionary of National Biography, Oxford University Press, 2004; online edition, Oct 2008, doi:10.1093/ ref:odnb/391

17. Mark Nicholls, "Strategy and Motivation in the Gunpowder Plot," The Historical Journal 50, no. 4 (2007): 788. doi:10.1017/s0018246x07006383

18. Margaret Aston, Broken Idols of the English Reformation (Cambridge, UK: Cambridge University Press, 2016), 375. doi:10.1017/cbog781139032834

19. Alexandra Walsham, "Skeletons in the Cupboard: Relics after the English Reformation," Past and Present 206, no. 15 (2010): 121-143. doi:10.1093/pastj/gtq015

20. Margaret Cox, "Eschatology, burial practice and continuity; a retrospection from Christ Church, Spitalfields," Grave Concerns: Death and Burial in England 170o1850, ed. Margaret Cox, (York, UK: Council for British Archaeology, 1998), 117. Louise Bashford and Tony Pollard, "'In the burying place' - the excavation of a Quaker burial ground," Grave Concerns, 165.

21. On the role of patronage and power in the cult of the saints and its continuities with the role of the patron in the late Roman world (along with other stories of wealthy patrons seeking proximity to their saintly ones), see Peter Robert Lamont Brown, The Cult of the Saints: Its Rise and Function in Latin Christianity, Haskell Lectures on History of Religions (Chicago: University of Chicago Press, 1981), 32-34. doi:10.7208/ chicago/9780226076386.001.0001

22. A similar distinguished burial, although from a different moment of acute stress and death, is the attributed burial of Captain Bartholomew Gosnold, also buried with his half pike with a cruciform top. See Erik R. Seeman, Death in the New World: Cross-Cultural Encounters, 1492-180o (Philadelphia: University of Pennsylvania Press, 2010), 81. doi:10.9783/9780812206005 See also “Captain's Burial,” Jamestown Rediscovery: Historic Jamestowne, accessed May 19, 2016, https://perma.cc/SUM3$\underline{\text { FRGL }}$

23. [1592 Recusant Roll] in Calendar of the Manuscripts of the Most Hon. the Marquis 
of Salisbury, Preserved at HatfieldHouse, Hertfordshire. Volume 4: 1590-1594 (London: Eyre and Spottiswoode, 1892), 268. Archer's father, "Christopher Archer of Mounsie," is listed among the recusants "remaining at liberty in the county of Essex." Archer was from Essex. His family appears in other recusant records as well: "Christopher Archer and his wife valued at $£_{30}$ in lands;" "The wife of Christopher Archer of Mountnessing, and Mrs. Laborne, living in the Archer's house," quoted in Jane Elisabeth Caspers, "Recusancy in Late Elizabethan Essex" (M.A. Thesis, The University of Western Ontario, 1975), 106-24.For a brief biography of Archer, see "Gabriel Archer," Virginia Immigrants and Adventurers, 1607-1635: A Biographical Dictionary, Martha W. McCartney ed., (Baltimore: Genealogical Publishing Company, 2007), 88. Another Archer relative recusant record can be found in, "Extract from Recusant Roll re: William Whately of Henley-in-Arden," circa 1580, Shakespeare Birthplace Trust, DR 37/2, Box 84, folder 22, National Archives, UK.

24. "The Church in Essex," The Tablet: The International Catholic News Weekly, June 9, 1956; Caspers, "Recusancy in Late Elizabethan Essex;” A. P. Baggs, Beryl Board, Philip Crummy, Claude Dove, Shirley Durgan, N R Goose, R B Pugh, Pamela Studd and C.C. Thornton. "Roman Catholicism," in A History of the County of Essex: Volume 9, the Borough of Colchester, ed. Janet Cooper and C. R. Elrington (London: Victoria County History, 1994), 338-339. [1592 Recusant Roll] in Calendar of the Manuscripts of the Most Hon. the Marquis of Salisbury, Preserved at Hatfield House, Hertfordshire. Volume 4: 1590-1594 (London: Eyre and Spottiswoode, 1892), 268. For a brief biography of Archer, see "Gabriel Archer," Virginia Immigrants and Adventurers, 1607-1635: A Biographical Dictionary, Martha W. McCartney ed., (Baltimore:

Genealogical Publishing Company, 2007), 88. Another possible Archer relative recusant record can be found in, "Extract from Recusant Roll re: William Whately of Henley-inArden,” circa 1580, Shakespeare Birthplace Trust, DR 37/2, Box 84, folder 22, National Archives, UK.

25. Gabriel Archer, "A Brief Description of the People," in Edward Wright Haile, Jamestown Narratives: Eyewitness Accounts of the Virginia Colony, the First Decade, 1607-1617, 1st ed. (Champlain, VA: RoundHouse, 1998), 124.

26. Ibid.

27. Gabriel Archer [attributed], "A relation of the discovery of our river from James Fort into the main, made by Captain Christofer Newport, and sicnerely [sic] written and observed by a gentleman of the colony," in Haile, Jamestown Narratives, 109. Eric Seeman rightly notes that a better symbol for the early Jamestown settlers was not the cross, but the "matchlock, the state-of-the-art English firearm, as this was a well-armed group anticipating hostile Indians." Seeman, Death in the New World, 79.

28. Ibid.

29. Ibid. 
30. Karen Ordahl Kupperman, The Jamestown Project (Cambridge, MA: Belknap Press of Harvard University Press, 2007), 12-23.

31. On the probability that Kendall may have been acting as a spy, or as it was known, "intelligencer," see Philip L. Barbour, "Captain George Kendall: Mutineer or Intelligencer?” The Virginia Magazine of History and Biography 70, no. 3 (1962): 31213 .

32. Edward Maria Wingfield, "A Discourse of Virginia," in Haile, Jamestown Narratives, 197-99.

33. Smith, The Complete Works of Captain John Smith (1580-1631) in Three Volumes, 3:296-97.

34. Ibid.

35. John Pory to Sir Edwin Sandys, June 12, 1620, in Virginia Company of London, The Records of the Virginia Company of London, ed. Susan M. Kingsbury, vol. 3 (Washington D.C.: Government Printing Office, 1933), 301-4.In understanding the Catholic-Protestant dynamics in early Jamestown I have benefited from Matthew John Sparacio, "The Devil in Virginia: Fear in Colonial Jamestown, 1607-1622" (Masters of Arts in History Thesis, Virginia Polytechnic Institute and State University, 2010), 42-43.

36. Ibid.

37. Ibid.

38. Ibid.

39. I have examined the extant religious artifacts in the collection of Jamestown Rediscovery. Thanks especially to Merry Outlaw, Curator, for her assistance, knowledge, and for allowing me to examine these objects in person. Many of these objects can be seen here: "Selected Artifacts: Religion," Jamestown Rediscovery, Historic Jamestowne, https://perma.cc/8PPH-H2TL For further information on the religious artifacts, see William M. Kelso, Jamestown, the Buried Truth (Charlottesville: University of Virginia Press, 2006), 187-88.

40. Kupperman, The Jamestown Project, 51-60.

41. The Low Countries and France specialized in "mass-produced," that is generic, workshop-made reliquaries to feed the surge of devotional interest in possessing containers to house the burgeoning market for relics, especially among elite families. Thanks to Bethany Donovan for her research on these objects. See [Unknown Artist] Reliquary, $13^{\text {th }}$ Century French. Object Number 1957.216, Harvard Art Museums/ Fogg Museum, Gift of Mrs. Jesse Isidor Straus in memory of her husband, Jesse Isidor Straus, Class of 1893. https://perma.cc/BXZ2-WAZ8 On the relic market, see Robert 
Bartlett, Why Can the Dead Do Such Great Things?: Saints and Worshippers from the Martyrs to the Reformation (Princeton, NJ: Princeton University Press, 2013), 304-8.

42. The reliquary that Bartlett writes about was from the Byzantine world. The silver content of the Jamestown reliquary suggests that it was made on the continent, perhaps in Spain where silver and devotional artifacts were produced in large numbers. Ibid., 266. On the silver content of the reliquary see, "Reliquary," Jamestown Rediscovery, https://perma.cc/YDA5-TGFM Dumbarton Oaks has two examples of this kind of capsae, see M. Ross, Jewelry, Enamels and Art of the Migration Period, Catalogue of the Byzantine and Early Mediaeval Antiquities in the Dumbarton Oaks Collection, Vol. II, (Washington, DC: 1965), no. 26-27, pl. XXV-XXVI.

43. Inventory of the Objects Forming the Collections of the Museum of Ornamental Art at South Kensington (London: George E. Eyre and William Spottiswoode, 1863), 12024 .

44. I am indebted to the insights and assistance of John Hanson, Assistant Curator of the Byzantine Collection at Dumbarton Oaks Research Library and Collection, Washington, D.C. in understanding the design of the Jamestown reliquary in relation to the long history of reliquary design.

45. Hahn observes that "reliquaries and their presentation from the beginning propose a complex instruction of the body and the senses, the teaching of reverentia." Cynthia J. Hahn, Strange Beauty: Issues in the Making and Meaning of Reliquaries, 40o-Circa 1204 (University Park, PA: Pennsylvania State University Press, 2012), 17. On the aesthetic theory of the period as it relates to the role of reliquaries in devotional life, see Cynthia Hahn, "The Spectacle of the Charismatic Body: Patrons, Artists, and Body-Part Reliquaries," in Hahn et al., Treasures of Heaven, 170.

46. Robert Bartlett notes, however, that in the period before the Reformation the historicity of a saint's remains had no bearing on the level of devotion or the importance of their cult. Bartlett, Why Can the Dead Do Such Great Things?, 33.

47. Brown, The Cult of the Saints, 4.

48. See Alexander Nagel, "The Afterlife of the Reliquary," Treasures of Heaven, 211-214.

49. John Calvin ended his extremely popular Traitté Des Reliques (1543) with a parting question and immensely influential critique of the provenance of relics. The 1561 English translation (sponsored by Elizabeth I) explains, "all is so mingled and confused, that one can not worshyp the bone of a Marter, but he shall be in danger to worship the bones of some certaine Murtherer or thefe, or els of an asse, or of a dog, or of a horsse, neither can one worshyp our ladyes [Our Lady's] ringes, or her comme [comb], or girdell [belt], but one shall be in danger of worshipping the ringes of some certaine hoore [whore]. Wherefore, take hede of the danger who so will for none from hense forth can pretende any excuse of ignoraunce." Jean Calvin, A Very Profitable Treatise: Made 
by M. Ihon Caluyne, Declarynge What Great Profit Might Come to Al Christendome, Yf There Were a Regester Made of All Sainctes Bodies and Other Reliques ... Set Furth and Authorised According to the Queenes Maiesties Iniunctions, trans. Stephen Wythers (London: By Rouland Hall, dwellyng in Goldyng lane at the sygne of the thre arrowes, 1561), 63. Philip Benedict writes that it was Calvin's most popular occasional work, going through twenty editions between 1543 and 1622. Philip Benedict, Christ's Churches Purely Reformed: A Social History of Calvinism (New Haven: Yale University Press, 2002), 91.

50. Nagel, “The Afterlife of the Reliquary," 211-212.

51. Walsham, "Skeletons in the Cupboard," 126.

52. Ibid., 127.

53. William Allen, A Briefe Historie of the Glorious Martyrdom of Xii. Reuerend Priests, Executed Vvithin These Tvveluemonethes for Confession and Defence of the Catholike Faith, Second (Rheins: J Foigny [attributed], 1582), 44. See also Robyn Malo, "Intimate Devotion: Recusant Martyrs and the Making of Relics in Post-Reformation England," Journal of Medieval and Early Modern Studies 44, no. 3 (2014): 53148. doi:10.1215/10829636-2791524

54. Walsham, "Skeletons in the Cupboard," 129.

55. Ibid. See also Malo, cited above.

56. The modern Catholic Church has codified this list of recusant martyrs as the "Forty Martyrs of England," Catholic men and women executed for treason from about 15351680. Of the forty martyrs that predate 1610, only one has an M in their last nameCuthbert Mayne. There are two women martyrs with first names that begin with the letter "M," Margaret Clitherow of York (martyred in 1586, executed by piling stones upon her for the crime of harboring priests, to Elizabeth I's chagrin, who thought as a woman she should have been spared) and Margaret Ward (hung for assisting a priest's escape from prison). Clitherow is the only of the two with any attributed relics; her hand is purportedly at the Bar Convent in York; Ward does not seem to have been dismembered, and her burial place is unknown. Both are not major recusant saints, compared to Mayne, with a thin record of material remains. Pope Paul VI canonized the forty martyrs, including Mayne, in 1970. For a listing of these see, Malcolm Pullan,The Lives and Times of the Forty Martyrs of England and Wales 1535-1680, Second Edition (London: Legend Press, 2013).

57. Alexandra Walsham, "Miracles and the Counter-Reformation Mission to England," The Historical Journal 46, no. 4 (2003): 794. doi:10.1017/ $\underline{\text { s0018246x03003303 }}$

58. David Hugh Farmer, "Mayne, Cuthbert," The Oxford Dictionary of Saints, $5^{\text {th }}$ edition 
[online], (Oxford University Press, 2011). Peter Lake, "A Tale of Two Episcopal Surveys: The Strange Fates of Edmund Grindal and Cuthbert Mayne Revisited: The Prothero Lecture," Transactions of the Royal Historical Society 18 (2008): passim, and 139-142. doi:10.1017/s0080440108000686

59. Raymond Francis Trudgian, "Mayne, Cuthbert [St Cuthbert Mayne]

(bap. 1544, d. 1577)," Oxford Dictionary of National Biography (Oxford University Press, 2004; online edition, Jan 2008) doi:10.1093/ref:odnb/18440 Helen Whelan, Snow on the Hedges: A Life of Cuthbert Mayne (Leominster [UK]: Fowler Wright Books, 1984), 98-102.Other sources on Mayne's life include R.A. McElroy, Blessed Cuthbert Mayne: Protomartyr of the English Seminaries (London: Sands Press, 1929).

6o. Christopher Pinney, "Things Happen: Or, From Which Moment Does That Object Come?” in Materiality, ed. Daniel Miller (Durham: Duke University Press), 256-72. doi:10.1215/9780822386711-011 Jules Prown made a similar point when he famously observed: "Objects created in the past are the only historical occurrences that continue to exist in the present." Jules David Prown, "Mind in Matter: An Introduction to Material Culture Theory and Method," Winterthur Portfolio 17, no. 1 (April 1, 1982): 3. doi:10.1086/496065

61. Michel Serres, Genesis, trans. Genevieve James and James Nielson, Studies in Literature and Science (Ann Arbor: University of Michigan Press, 1995), 87. doi:10.3998/mpub.14807

62. On the development of England's "Protestant empire" see Carla Gardina Pestana, Protestant Empire: Religion and the Making of the British Atlantic World (Philadelphia: University of Pennsylvania Press, 2009). doi:10.9783/9780812203493

\section{Yale}

Copyright 2016 Yale University All rights reserved. 